\title{
The Save KPK Movement: A Framing Analysis of Coverage in Indonesian News Media Surrounding the KPK and Police Dispute
}

\author{
Achmad Jamil \\ Faculty of Communication, Mercu Buana University, Indonesia; achmadjamil.umb@gmail.com
}

Caturida Meiwanto Doktoralina

Faculty of Economics and Business, Mercu Buana University, Indonesia; chess302@gmail.com

Doi:10.5901/mjss.2016.v7n3s1p229

\begin{abstract}
Previous studies focusing on protest and social movement mostly concern identifying marginalization strategies that the media used to delegitimize the movement. This study attempted to examine how Indonesian mainstream media framed the Save KPK movement which emerged as a result of the dispute between the KPK and the Police. This study viewed these two institutions as collective and competing actors that represent certain interests and pursue the legality of their actions. In particular, this study proposed a typology of five framing devices used in the coverage of the Save KPK movement and explored the occurrence of framing strategies and the overall tone of the news coverage of the movement. A total of 246 articles on the Save KPK Movement was derived from the two most influential elite newspapers in Indonesia: the Kompas and the Media Indonesia. The Media Indonesia had 138 articles, while the Kompas published 108 articles. The results show that conflict, morality, and responsibility are the three framing devices mostly used in media coverage of the Save KPK movement. Further, the results demonstrated that the social movement organizations seem to be successful in the process of diagnostic, prognostic, and motivational framing. The results of this study provide more insight concerning framing strategies and media contents could be applied to be effective in shaping public opinion. In particular, the results highlight the positive side of the social movement organizations and their actions could strengthen the support of the public for the consequences of that target group.
\end{abstract}

Keywords: Save KPK movement, dispute, media framing device, public support

\section{Introduction}

In recent years, the government of Indonesia has put a strong fundament of policy to fight against corruption (HamiltonHart, 2001). In order to realize its law supremacy, the government passed Law No. 30 of 2002 on the Corruption Eradication Commission in 2002, providing a legal basis for the establishment of the Indonesian Corruption Eradication Commission (Indonesian: Komisi Pemberantasan Korupsi), or better known as KPK. According to the KPK Law, the KPK focuses on the following corrupt acts. First, it involves government officers, law enforcers, and other individuals connected to corrupt acts perpetrated by government officers or law enforcer. Second, it has generated significant public concern. Third, it has lost the state at least IDR 1 million. The vision of the KPK is being an independent anticorruption institution that is capable to free Indonesia from corruption (Febri and Lie, 2010). To support its operation, the KPK Law sets out the following KPK's authority, powers and duties: First, it does a coordination with institutions authorized to combat acts of corruption, second, supervising institutions authorized to combat acts of corruption, third, conducting preliminary investigations, investigations and prosecutions against acts of corruption, fourth, conducting corruption prevention activities, and fifth, conducting monitoring of state governance.

Since it started operating in late 2003, the KPK has become a fiercely independent and successful anticorruption institution. It has demonstrated excellent works by imprisoning hundreds of high-profile guilty persons, including businessmen, politicians, and government officials (Tjiptoherijanto, 2009). While activists and interest group often urge the KPK to be more aggressive in its work, however, the success of the KPK is a source of controversy in Indonesia (Febri and Lie, 2010). Many observers noted that the KPK sometimes quite aggressive, in pursuing high-level targets like governors, lawmakers, bureaucrats, prosecutors, and police officials. Such a condition has led to something of a backlash, i.e., attempts to undermine the KPK. Accordingly, it is not surprising that the KPK has made many enemies who are continually trying to undermine the KPK as an anticorruption institution. Some of the severe resistance to the 
KPK has come from the Indonesian National Police Force, which has emerged into a dramatic dispute (Nurfauzia, 2015).

The first dispute between the KPK and the police occurred in 2009. The dispute between the two law enforcement institutions was triggered by a statement made by Commander General Susno Duadji, who coined the phrase Gecko challenging a Crocodile in expressing his low opinion of the KPK. Duadji, the head of the National Police's Criminal Investigations Directorate compared the KPK to a Gecko and likening the police to a Crocodile. Soon, the image of a Gecko challenging a Crocodile became a popular symbol in the country, giving rise to a social movement in support of the Gecko (Cahyaningrum, 2012). Many activists, journalists, prominent figures, and ordinary civilians spontaneously joined hands to support the Gecko in fighting the Crocodile, and the term of Gecko vs. Crocodile has become a symbol in a public anti-corruption campaign. Given the widespread reaction, not long after, the Indonesian National Police Chief General Bambang Hendarso Danuri apologized to the public for the statement made by one of his staff officers. Danuri underlined that the gecko challenging a crocodile analogy did not represent the views of the National Police. It was stated by Duadji in his personal capacity, and begged everyone to stop using it. However, the police underestimated the KPK. Ultimately, Duadji was found guilty. The Gecko won and the Crocodile loose (Nurfauzia, 2015).

The second episode of the KPK and Police dispute was occurring in 2012. The dispute mainly is concerned with a corrupt driving license simulator procurement project involving high-profile persons in the Indonesian National Police Traffic Corps (Hamdan, 2014). Following its investigation, the KPK detained Chief Inspector General Djoko Susilo as the main graft suspect for his involvement in the project. Susilo himself was the head of the National Police Traffic Corps. This KPK work could be considered as a special moment in the legal process occurring in Indonesia as Susilo is a high profile person and is an active police general detained in a graft case by the KPK (Nugroho and Syarief, 2012). The police struck back the KPK by arresting KPK investigator Novel Baswedan on charges related to shooting theft suspects in 2004. The police claimed Baswedan took responsibility for the actions of his men when he serves as the head of the Bengkulu criminal unit, resulting one suspect died. Again, the police underestimates the KPK. News of the police action spread rapidly through various media. Soon, many activists, journalists, prominent figures, and ordinary civilians flocked to the KPK building to show their support for the commission. These KPK supporters spontaneously joined hands to make a barrier encircling the KPK building to block the police movement. The police eventually retreated and left the KPK building and "Save KPK" movement and Gecko vs. Crocodile Round 2 quickly became a popular symbol in the country. The investigation into Baswedan was suspended following the instruction from President Yudhoyono, and Susilo was eventually found guilty (Nurfauzia, 2015).

This study focuses on the second episode of the KPK and Police dispute because during July - September 2012, a historic event occurred in Indonesia: the Save KPK movement. This movement was attributed to issues concerning the KPK undermining efforts conducted by other parties, particularly the Police and gained widespread media coverage. Previous studies indicated that the media is an important tool toward the integration of competing groups and societies (Yang and Ishak, 2012). Yet, the comparisons of framing strategies utilized by the Save KPK movement surrounding the KPK and Police dispute remain largely unexplored. The objective of this study, therefore, is to compare the coverage of the Save KPK movement involved in the KPK and Police dispute by the Indonesian mainstream newspapers. Using a framing analysis, this study aims to seek the answer of the following matters; the extent of coverage of Save KPK movement, the news sources used by the newspapers, the news frame used by the newspapers, and the slant of the news articles. The results of this study would provide a more understanding on the Save KPK movement objectively; provide insight into the concerns and attitudes of both the KPK and Police based on their own perspectives and agendas; and foster the newspapers awareness to evaluate its role in promoting consensus and integration. This paper consists of five sections, starting with this introduction (Section 1). Section 2 follows to the theoretical framework. Section 3 introduces the research methodology. Section 4 presents the results. Lastly, Section 5 presents the conclusions of the study.

\section{Media Framing and Social Movements}

According to Scheufele (1999), the concept of framing could be distinguished into two: media frame and individual frame. Yousaf (2015) describes media frame as the words, images, and presentation style employed by news agency to relay information about an event or an issue to the audience. In this sense, the news agency need to decide which aspects of the information should be deemed relevant, salient, and appropriate to be delivered to the audience. Meanwhile, individual frame is concerned with what an individual receiver of information believes to be the most relevant, salient, and appropriate aspects of information. This study focuses on the former type of framing. Cissel (2012) conceptualizes media framing as the way in which information is presented to its audiences.

The concept of framing, originated by the cognitive psychology and anthropology scholars, recently has been used widely adopted by other disciplines, including communications science, sociology, economics, and social movement 
research (Yang and Ishak, 2012). According to Entman (1993), framing essentially involves selection and salience; and is defined as "selecting some aspects of a perceived reality and make them more salient in a communicating text, in such a way as to promote a particular problem definition, causal interpretation, moral evaluation, and/or treatment recommendation for the item described". In this perspective, Entman (2004) states that "definition of problems, causal analysis, evaluation and remedy are framing functions that interrelated, compose the frame, the narrative. The objects of framing may be issues, events or actors, whether they are individual leaders, groups or nations". Furthermore, Griffin (2003) conceptualizes framing as "the process of calling attention to some aspects of reality while obscuring others, which might lead to different reactions." Meanwhile, Scheufele and Tewksbury (2007) asserted framing as "the selection process of a restricted number of thematically related attributes for inclusion in the media agenda when a particular object is discussed".

News media and social movement are closely related as a social movement organization (SMO) often utilizes news media to communicate its goals and assertions (Baylor, 1996). Snow and Benford (1988) describe that SMO utilized frames to engage supporters, recruit new supporters, and motivate supporters to act in ways congruent with the SMO objective. Snow and Benford further identify three core framing processes utilized by SMOs to accomplish these tasks: diagnostic framing, prognostic framing, and motivational framing. In this perspective, diagnostic framing is concerned with the identification a problem in need of a remedy; prognostic framing is related to the proposition a solution to the problem; and motivational framing refers to the representation the call to action. Similarly, Snow et al. (1986) identified frame as the strategy utilized by SMO for mobilization whereby they articulate how individual interests, values, and beliefs are going well together with the SMO objective. In particular, Snow et al. (1986) found four major strategies for frame: bridging, amplification, extension, and transformation. This enables SMO to link two or more similar frames, reach out to other potential supporters, and redefine what is meaningful within one frame to another frame. However, as underlined by Baylor (1996), the relationship between news media and social movement is usually unequal. Many smaller SMOs lack the resources to utilize news media compared to larger SMOs that have enough resources to arrange their own media. In this sense, news media enjoys the advantage of multiple stories or events from which they can choose and determine the stories they cover. Therefore, SMO should exercise caution when the media is involved. The rationale is that the way in which the media frames issues affect publics' views. Such a condition is very likely influence public's awareness, contributions, and support.

\section{Research Methodology}

This study applied a qualitative method in examining the media framing on the Save KPK movement surrounding the KPK and Police dispute case. Azpiroz (2014) describes the benefit of using qualitative methodology such as content analysis, discourse analysis, focus groups, and interviews. First, the methodology allows the researcher to identify and measure all the elements of the frame. Second, the methodology enables the researcher to approach research in a flexible and intuitive way, wherein the own researcher serves as the main tool of analysis. Third, the methodology enables the researcher to describe and interpret the qualities of a phenomenon in its context and to achieve a deep understanding. Forth, the methodology has a more realistic and contextualized interpretive look. In other words, the methodology doesn't overlook the presence of elements with a high symbolic content. Lastly the methodology enables the researcher to interpret the results beyond content, since the context where the words are located is also interpreted.

Data for the current study were collected from articles published by two Indonesian daily newspapers: Kompas and Media Indonesia. The Kompas widely recognized as the most influential elite newspaper in Indonesia. Media Indonesia is a popular newspaper that had the second-largest circulation in Indonesia (Nugroho and Syarief, 2012). This study analyzed articles of coverage from the Kompas and Media Indonesia about the Save KPK movement during July December 2012. Following previous studies (Yang and Ishak, 2012; Xu et al., 2013), this study adopted and modified the five news frames in the coverage of the issue being studied: conflict, human interests, consequences, morality and responsibility. Table 1 presents the frames used in this study with their operational definitions. 
Table 1. Frames used in this study with their operational definitions

\begin{tabular}{ll}
\hline \multicolumn{1}{c}{ Frame } & \multicolumn{1}{c}{ Operationalisation } \\
\hline 1. Conflict & a. emphasizes conflict among and between individuals, groups, \\
parties, or institutions as a means of capturing audience interest \\
b. reflects disagreement among and between individuals, groups, \\
parties, or institutions \\
c. an individual, group, party, or institutional reproach \\
d. dichotom izes or labels the good and bad \\
e. news item refers to two sides instead of more than two sides of \\
the issue/problem \\
f. news items refer to winners and losers
\end{tabular}

\section{Findings}

\subsection{Descriptive analysis}

A total of 446 sample articles on the Save KPK movement was collected from the two newspapers: Kompas and Media Indonesia. In this perspective, Kompas contributed 208 articles and Media Indonesia contributed 238 articles. The unit of analysis was the article, which is distinguished into five: straight news, editorials, columns, letters, and opinions. As shown in Table 2, the majority of the sample articles published by the Kompas ( $n=132 ; 63.46 \%)$ can be categorized as straight news. This was followed by column articles $(n=29 ; 13.94 \%)$, letters articles $(n=25 ; 12.02 \%)$, editorials articles $(n=17 ; 8.17 \%)$, and opinions articles $(n=5 ; 2.40 \%)$. As for articles published by the Media Indonesia, the results showed that the majority of the sample articles $(n=166 ; 69.75 \%)$ can be categorized as straight news. This was followed by editorials articles ( $n=29 ; 12.8 \%)$, letters articles $(n=23 ; 9.66 \%)$, column articles $(n=11 ; 4.62 \%)$, and opinions articles $(n=9$; $3.78 \%$ ). The average length of sample articles published by the Kompas was 416 words, with the longest article consisting of 618 words and the shortest, 78 words. Meanwhile, the average length of sample articles published by the Media Indonesia was 538 words, with the longest article containing 702 words and the shortest, 89 words.

Table 2. Extent of coverage for the Save KPK movement

\begin{tabular}{lcccc}
\hline \multirow{2}{*}{ Types of article } & \multicolumn{2}{c}{ Kompas } & \multicolumn{2}{c}{ Media Indonesia } \\
\cline { 2 - 5 } & $\mathrm{n}$ & $\%$ & $\mathrm{n}$ & $\%$ \\
\hline Straight news & 132 & 63.46 & 166 & 69.75 \\
Editorials & 17 & 8.17 & 29 & 12.18 \\
Columns & 29 & 13.94 & 11 & 4.62 \\
Letters & 25 & 12.02 & 23 & 9.66 \\
Opinions & 5 & 2.40 & 9 & 3.78 \\
\hline Size (mean) & \multicolumn{2}{c}{416 words } & \multicolumn{2}{c}{538 words } \\
\hline
\end{tabular}


Table 3. News sources for the Save KPK movement

\begin{tabular}{lcccc}
\hline \multirow{2}{*}{ News sources } & \multicolumn{2}{c}{ Kompas } & \multicolumn{2}{c}{ Media Indonesia } \\
\cline { 2 - 5 } & $\mathrm{n}$ & $\%$ & $\mathrm{n}$ & $\%$ \\
\hline Leaders of parties & 19 & 9.13 & 46 & 19.33 \\
Police officers & 38 & 18.27 & 58 & 24.37 \\
KPK officers & 22 & 10.58 & 34 & 14.29 \\
Lawyers & 20 & 9.62 & 54 & 22.69 \\
NGOs & 41 & 19.71 & 23 & 9.66 \\
Civilians & 61 & 29.33 & 14 & 5.88 \\
Others & 7 & 3.37 & 9 & 3.78 \\
\hline
\end{tabular}

This study categorizes news sources for the Save KPK movement into seven: leaders of party, police officer, KPK officer, lawyer, NGO, civilian, and others. As shown in Table 3, the Kompas used the civilians as its most important news sources $(n=61 ; 29.33 \%)$. After that, the Kompas used NGOs as its news sources ( $n=41 ; 19.71 \%)$, police officers $(n=38$; $18.27 \%)$, KPK officers $(n=22 ; 10.58 \%)$, lawyers $(n=20 ; 9.62 \%)$, leaders of parties $(n=19 ; 9.13 \%)$, and others $(n=7$; 3.37\%). In contrast, the Media Indonesia turned to police officers as its dominant news source $(n=58 ; 24.37 \%)$. This was followed by lawyers as its news sources ( $n=54 ; 22.69 \%)$, leaders of parties ( $n=46 ; 19.33 \%)$, KPK officers $(n=34 ; 14.29 \%)$, NGOs $(n=23 ; 9.66 \%)$, the civilians ( $n=14 ; 5.88 \%)$, and others $(n=9 ; 3.38 \%)$.

\subsection{News Frames for the Save KPK movement}

The research question of this study is concerned with the most frequently used frames in news coverage surrounding the Save KPK movement. In this perspective, this study categorizes news frames for the Save KPK movement into five: conflict, human interests, consequences, morality, and responsibility. These five news frames are the five most commonly used news frames in the coverage of a range of issues, as Semetko and Valkenburg (2000) identified.

Table 4. News Frames for the Save KPK movement

\begin{tabular}{lcccc}
\hline \multirow{2}{*}{ News frames } & \multicolumn{2}{c}{ Kompas } & \multicolumn{2}{c}{ Media Indonesia } \\
\cline { 2 - 5 } & $\mathrm{n}$ & $\%$ & $\mathrm{n}$ & $\%$ \\
\hline Conflict & 59 & 28.37 & 88 & 36.97 \\
Consequences & 39 & 18.75 & 37 & 15.55 \\
Responsibility & 46 & 22.12 & 42 & 17.65 \\
Moral & 47 & 22.60 & 50 & 21.01 \\
Human Interest & 17 & 8.17 & 21 & 8.82 \\
\hline
\end{tabular}

\subsubsection{The Conflict Frame}

As can be seen in Table 4, it was found that the most salient frame found in the sample articles published by the Kompas $(n=59 ; 28.37 \%)$ and the Media Indonesia ( $n=88 ; 36.97 \%)$ was conflict frame. By imposing the conflict frame, both the Kompas and the Media Indonesia emphasizes conflict the KPK and police as a means of capturing audience interest. For example, a Media Indonesia article, entitled "Gecko VS crocodile round two" best exemplified a conflict frame. The dispute between the KPK and police began when the KPK named Susno Djuadi, the National Police Traffic Corps Chief, as a graft suspect for his involvement in a corrupt driving simulator procurement project. When asked about the KPK investigations into the police, Duadji stated the KPK's attempt to challenge him or other members of the police force. Djuadi further claimed that it was like a gecko (the KPK) challenging a crocodile (the police). The police strike back against the KPK by naming two KPK commissioners, Chandra Hamzah and Bibit Samad Rianto, as graft suspect. In addition, the police arrested KPK Chief Antasari Azhar for murder. Many individuals and groups question the charges against the KPK Chief Antasari Azhar and the two KPK commissioners, Chandra Hamzah and Bibit Samad Rianto. They believed that the charges were entirely conspiracy. It is a deliberate attempt by senior police officials to undermine the KPK. The police underestimated the KPK as civil society saves the KPK with an outpouring of support. Civil society forced President Susilo Bambang Yudhoyono to undertake an independent investigation. As a result, the KPK commissioners were cleared and Duadji was found guilty. The KPK won and the police loose. 


\subsubsection{The Consequences frame}

By imposing the consequences frame, the Kompas and the Media Indonesia focused on the event, issue or problem in terms of the consequences on individuals, groups, parties, institutions, or the country. In addition, the consequences frame is also concerned with the outcome of a court case. When examining the presence of the Save KPK movement frames (Table 4), it was found that the sample articles published by the Kompas ( $n=39 ; 18.75 \%)$ and the Media Indonesia $(n=37 ; 15.55 \%)$ were consequences frame. For instance, it is reported that the cost of corruption has an important impact in the economy of Indonesia. The Indonesian Corruption Watch highlights corruption is very likely affects the foreign investor's decision to invest in Indonesia. In addition, corruption will damage the governmental accountability and break the rule of law of Indonesia, which is needed for economic and political stability to attract foreign investors. It was also reported that the KPK detained Chief Inspector General Djoko Susilo as a graft suspect for his involvement in a corrupt driving simulator procurement project. His detention is a special moment in the legal process occurring in Indonesia as Susilo is a high profile person and is an active police general detained in a graft case by the KPK. In his interview, Susilo told reporters that he respected the questioning and he will accede to the legal process, including by being detained. KMS Roni, the lead prosecutor of the Jakarta Corruption Court, said Djoko should be found guilty of colluding with Brig. Gen. Didik Purnomo and other parties to inflate the 2011 driving simulator procurement budget, which allegedly caused IDR 144.9 billion (US\$13.53 million) in state losses.

\subsubsection{The Responsibility frame}

Responsibility was another frame imposed by the Kompas ( $n=46 ; 22.12 \%)$ and the Media Indonesia $(n=42 ; 17.65 \%)$. Through responsibility frame, these two newspapers present the articles concerning the dispute between the KPK and police in such a way as to attribute responsibility for its cause or solution to either the government, institution, or to an individual, group and party. For instance, one of the KPK deputy chairman, Busyro Muqoddas, stated that the KPK had been undermined by the lack of investigators since the commission has been investigating several cases involving highprofile persons. Therefore, the KPK had sent a completed draft revision of the regulation to the President, hoping the President to sign the regulation in order to solve the KPK problems. Busyro further demand the president Yudhoyono to renew his commitment by letting the KPK to extend the tenures of the KPK investigators for up to 12 years. Therefore, the work of the KPK in eradicating corruption in the country would be effective. It was also reported that the president Yudhoyono was upset by the fact that he cannot enforce his authority of the police and his directive had not been realized. In his speech, the president Yudhoyono has finally took a real action by ordering the police to allow the KPK investigate the driving simulator procurement case, stressing the withdraw police investigators being seconded to the KPK was inappropriate. In similar, it was also reported that Oce Madril, one of the analyst from the Gadjah Mada University's Center for Anticorruption Studies suggested the president Yudhoyono to take a real action immediately to resolve the dispute between the KPK and police. He further underlined that the dispute is actually a test for Yudhoyono to prove his commitment in eradicating corruption occurring in the country. In this perspective, Madril stressed that the lack of KPK resources would provide a negative impact on the enforcement of corruption cases.

\subsubsection{The moral frame}

Through the moral frame, the Kompas and the Media Indonesia put the dispute between the KPK and Police in the context of religious tenets or moral, in addition to emphasizes cooperation and unity. As seen in Table 4, it was found that the sample articles published by the Kompas ( $n=47 ; 22.60 \%$ ) and the Media Indonesia ( $n=50 ; 21.01 \%$ ) were moral frame. For example, it was reported that one of the KPK commissioners admitted that the commission has limited resources. Considering that to run the KPK in Indonesia is expensive, accordingly, the commission needs to be careful and selective in the recruitment of its personnel and executives. He further claimed that being an independent anticorruption institution, the KPK needs to possess sufficient resources and powers to carry on its function. Towards this end, he suggested the Indonesian government to provide the KPK with sufficient funding, facilities, and competent personnel as well. This government support indicates the political will in eradicating corruption in the country. It was also published by the Media Indonesia reported that on October 5, a group of police officers besieged the KPK office in Jakarta, intending to arrest KPK investigator, Novel Baswedan on charges related to shooting theft suspects in 2004. The police stated that Baswedan took responsibility for the actions of his men when he serves as the head of the Bengkulu criminal unit. The police argued that his unit officers shot six thieves during a robbery in progress, resulting one suspect died. However, Bambang Widjajanto, one of the KPK deputy chairman, questioning the charge on Baswedan; stating the police has 
made up the case. Widjajanto claimed the Baswedan case was closed in 2004 as the police's ethics board cleared Novel of any wrongdoing. Widjajanto further argued that the charge on Baswedan was just a part of a systematic attempt conducted by the police to undermine the KPK. The charge is related to the position of Baswedan as the head of the KPK investigator team for the driving simulator procurement case.

\subsubsection{The human interest frame}

Under the human interest frame, the Kompas and the Media Indonesia emphasizes how individuals and groups are affected by the dispute between the KPK and Police. As can be seen in Table 3, it was found that the sample articles published by the Kompas $(n=17 ; 8.17 \%)$ and the Media Indonesia $(n=21 ; 8.82 \%)$ was human interest frame. For example, it was reported that Novel Baswedan, an investigator who joined the KPK in 2007 after 10 years with the national police stated to the media that provided more insight concerning his and many of his motivation, and also many of his colleagues in joining the KPK. He described that many of KPK's investigators came from the national police, which are also empowered to investigate corruption cases. Yet, the police itself riddled with corruption. There is a culture of corruption that is so entrenched in the police institution, and he decided on a career in police work in order to do good deeds. It was also reported that a group of police officers tried to enter the KPK office located on JI. HR Rasuna Said, Jakarta in an attempt to arrest the KPK investigator Novel Bawesdan. News of the police action spread rapidly through various media. Soon, many activists, journalists, prominent figures, and ordinary civilians flocked to the KPK headquarters building to show their support for the anticorruption institution. Although several police officers were attempting to forcibly enter the KPK building, many activists, journalists, prominent figures, and ordinary civilians spontaneously joined hands to make a barrier encircling the KPK building to block the police movement. The police eventually retreated and left the KPK building and "Save KPK" movement quickly became popular in the country.

\section{Conclusion}

In recent years, the government of Indonesia has put a strong fundament of policy to fight against corruption since the government passed Law No. 30 of 2002 on the Corruption Eradication Commission in 2002. The passing of the Law provides a legal basis for the establishment of the Indonesian Corruption Eradication Commission (Indonesian: Komisi Pemberantasan Korupsi), or better known as KPK. As has been an independent anticorruption institution, the KPK has demonstrated excellent works by imprisoning hundreds of high-profile guilty persons, including businessmen, politicians, and government officials. This has led to something of a backlash, i.e., attempts to undermine the KPK. Accordingly, it is not surprising that the KPK has made many enemies who are continually trying to undermine the KPK as an anticorruption institution. Some of the severe resistance to the KPK has come from the Indonesian National Police, which has emerged into dramatic dispute.

This study focuses on the second episode of the KPK and Police dispute because during July - September 2012, a historic event occurred in Indonesia: the Save KPK movement. This movement was attributed to issues concerning the KPK undermining efforts conducted by other parties, particularly the Police and gained widespread media coverage. The dispute was also characterized by the police siege against the KPK building in Jakarta as an effort to arrest the KPK investigator Novel Bawesdan. Soon, many activists, journalists, prominent figures, and ordinary civilians flocked to the KPK building to show their support for the anticorruption institution. They spontaneously joined hands to make a barrier encircling the KPK building to block the police movement. The police eventually retreated and left the KPK building. Not long after, the Save KPK movement quickly became popular actions in the country.

In particular, this study examines the representation of the Save KPK movement in the two Indonesian daily newspapers in the context of the KPK and police dispute. Following Entman (1993), this study viewed that framing is concerned with salience, i.e., what kind of information is elucidated and emphasized by these two competing institutions, which includes omitting or downplaying certain aspects of the three issues being studied. In other words, framing is concerned with how these two competing institutions package a message according to a certain understanding of these three issues. In addition, as suggested by Benford and Snow (2000), this study recognizes that framing is a processes composing of diagnostic, prognostic, and motivational framing. In this perspective, diagnostic framing concerned with how the KPK and the Police defined and described the three issues being studied; prognostic framing involves how these two anti-corruption institutions proposed and described what should be done by them; and motivational framing relates to the rationale and clarification why the actions suggested by the KPK and the Police are needed. This study viewed these two institutions as collective actors that represent certain interests and pursue the legality of their actions

A total of 446 articles on the Save KPK movement was derived from the two daily newspapers: Kompas and Media 
Indonesia. Media Indonesia scored 238 articles and Kompas published 208 articles. Media Indonesia also topping in terms of the average number of words, 538 words, followed by the Kompas with 416 words. The data demonstrated that there was no gap between the units of the article, which is distinguished into five: straight news, editorials, columns, letters, and opinions. This study also explores the source of news used by the two newspapers in publishing their articles. The rationale is that to some extent, the source of news is the story and is very likely to determine the basic nature of the articles, as Entman (1993) argued. In this matter, this study found that the Kompas used the civilians as its most important news sources, while the Media Indonesia turned to police officers as its dominant news source. Next, this study concerned the most frequently used frames in news coverage surrounding the Save KPK movement, which was categorized into five: conflict, human interests, consequences, morality, and responsibility. In this sense, it is important to note that the most salient frame found in the articles published by the Kompas and the Media Indonesia was conflict. By imposing the conflict frame, both the Kompas and the Media Indonesia emphasizes conflict the KPK and police as a means of capturing audience interest.

This study has attempted to examine how the media framed the Save KPK movement which emerged as a result of the dispute between the KPK and police. The results of this study provide a more understanding concerning news coverage of the Save KPK movement and to the literature of protest and social movement framing. In particular, this study proposed a typology of five framing devices used in the coverage of the Save KPK movement and explored the occurrence of framing strategies and the overall tone of the news coverage of the movement. This study offers practical implications for the state and the media agency in Indonesia. It is believed that the news media serve as an influential agency in the formation of public opinion, particularly in context of eradicating corruption occurring in the country.

However, the contribution of this study is qualified by certain limitations. First, the identified time period of six months during the dispute might limit the variety of the media frames. Therefore, a comprehensive picture regarding the framing of the Save KPK movement in the Indonesian mainstream newspaper might not have been presented. Second, this study focused on the Indonesian two daily newspapers. Future research should investigate the representation of the Save KPK movement in other Indonesian mainstream newspaper agencies, such as other daily newspapers, television news, and alternative media avenues to understand the generalizability of the findings.

\section{References}

Azpiroz, M.L. (2014). "Framing and Political Discourse Analysis: Bush's trip to Europe in 2005", Observatorio Journal, 8 (3), 75-96

Baylor, T. (1996), "Media framing of movement protest: the case of American Indian protest", The Social Science Journal, 33 (3), $241-$ 2.51

Benford, R.D. (1997). "An Insider's Critique of the Social Movement Framing Perspective", Sociological Inquiry, 67 (4), $409-430$

Benford, R.D. and Snow, D.A. (2000), "Framing Processes and Social Movements: An Overview and Assessment", Annual Review of Sociology, 26, 611-39

Cahyaningrum, D. (2012). "Kewenangan KPK versus Polri dalam Penyidikan Dugaan Korupsi Pengadaan Simulator Pembuatan Surat Izin Mengemudi di Korlantas Polri", Info Singkat Hukum, 4 (15), 1-4

Cissel, M. (2012), "Media Framing: a comparative content analysis on mainstream and alternative news coverage of Occupy Wall Street ", The Elon Journal of Undergraduate Research in Communications, 3 (1), 67-77

Entman, R.M. (1993), "Framing: Toward Clarification of a Fractured Paradigm", Journal of Communication, 43(4), 51-58

Entman, R.M. (2004), "Projections of Power: Framing News, Public Opinion and U.S. Foreign Policy", University of Chicago Press, Chicago.

Febri, R. and Lie, A. (2010), "The Face of Law Supremacy: A Media Content Analysis on Artalyta's Luxurious Prison Case on The Jakarta Globe Newspaper", The Indonesian Journal of Communication Studies, 3 (1), 15-29

Griffin, E. A. (2003), "A First Look at Communication Theory", McGraw-Hill Inc., San Francisco

Hamdan (2014), "Analisis Framing Berita Perseteruan KKP dan Polri di Media Kompas.Com Dan Vivanews.Com" Journal IImu Komunikasi, 2(4), $171-183$

Hamilton-Hart, N. (2001). "Anti-Corruption Strategies in Indonesia", Bulletin of Indonesian Economic Studies, 37 (1), 65-82

Nugroho, Y. and Syarief, S.S. ( 2012). "Beyond Click-Activism? New Media and Political Processes in Contemporary Indonesia", Friedrich-Ebert-Stiftung, Berlin, ISBN: 978-602-8866-05-7

Nurfauzia, S. (2015), "Gecko vs. Crocodile, Round Three: Indonesia's Ongoing Fight between the Police and the KPK", available at http://globalanticorruptionblog.com

Scheufele, D. A. and Tewksbury, D. (2007), "Framing, Agenda Setting, and Priming: The Evolution of Three Media Effects Models", Journal of Communication, 57, 9-20

Scheufele, D.A. (1999). "Framing as a Theory of Media Effects", Journal of Communication, 49 (1), 103-122

Semetko, H.A. and Valkenburg, P.M. (2000), "Framing European politics: A content analysis of press and television news", Journal of Communication, 50 (2), 93-109

Tjiptoherijanto, P. (2009), "Corruption Prevention in Indonesia", Indonesia University, available at http://unpan1.un.org 
Xu, K. (2013), "Framing Occupy Wall Street: A Content Analysis of The New York Times and USA Today", International Journal of Communication, 7, 2412-2432

Yang, L.F. and Ishak, M.S.A. (2012), "Framing Interethnic Conflict in Malaysia: A Comparative Analysis of Newspaper Coverage on the Hindu Rights Action Force (Hindraf)", International Journal of Communication, 6, 166-189

Yousaf, S. (2015). "Representations of Pakistan: A Framing Analysis of Coverage in the U.S. and Chinese News Media Surrounding Operation Zarb-e-Azb", International Journal of Communication, 9, 3042-3064 